\title{
JOURNAL.RU
}

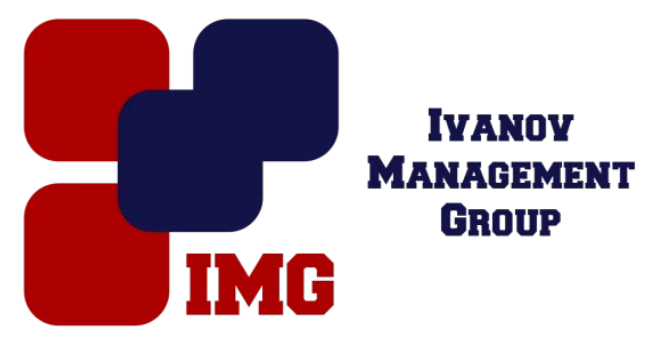

Белоус Д.С., Мельников И.Н., Пичхидзе С.Я., Кайргалиев Д.В., Ермошин А.Г . ФГБОУ ВО «Саратовский государственный технический университет им. Гагарина Ю.А.»

Саратов, Россия

doi: 10.18411/lj-30-11-2016-4-01

idsp 000001:lj-30-11-2016-4-01

\section{Антифризы в огнетушащих составах}

\section{Аннотация}

Рассмотрены антикоррозионные свойства антифризов.

Ключевые слова: этиленгликоль, антифриз.

В качестве жидкости с пониженной температурой замерзания в огнетушащих составах могут быть использованы автомобильные антифризы и тосолы, например, Аляска тосол -40» (ГОСТ 28084) [1].

Полученные нами результаты свидетельствуют о том, что антифриз «Аляsка тосол -40» обладает антикоррозионными свойствами. При содержании «Аляsка тосол -40» в количестве $1 \%$ мас. в водном растворе существенно повышало антикоррозионную стойкость углеродистой стали $[2,3]$.

\section{Литература}

1. Неверо А.С., Мельников И.Н., Муктаров О.Д. Ликвидация пожара огнетушащим составом с антифризом. В сборнике: Юридическая наука и практика: традиции и новации Сборник статей Международной научнопрактической конференции. 2016. С. 112-113.

2. Хаврошина Ю.О., Белоус Д.С. Разработка огнестойких составов для пропитки огнезащитных костюмов пожарных и спасателей. http://www.school-science.ru/2017/19/26192

3. Никонович С.Л., Мельников И.Н., Кайргалиев Д.В. К созданию огнетушащих составов, применимых в условиях суровой зимы. В сборнике: Современные тенденции развития правовой науки Международная научно-практическая конференция. 2016. С. 198-201. 